DOI :

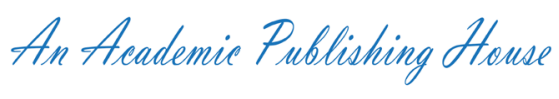

\title{
"My Last Duchess" Poem from a Psychosocial and Social Point of View
}

\author{
Dr. AMAL. M. A. IBRAHIM
}

Assistant Professor, English Department, Al Baha University College of Science \& Art Almikhwa, Saudi Arabia.

\begin{abstract}
The purpose of this study is to examine Robert Browning's poem "My Last Duchess" (1842) from a psychosocial point of view. It intends to analyze the poem using some concepts such as the rule of jealousy and possession pride, arrogance, and murder. The reason why the study chooses to use these particular concepts is that the psychosocial phenomena they represent play a major role in this poem. The main character in the poem can be considered to belong to these concepts. It led him to jealousy, which led to the commission of the murder. The researcher recommended that the psychological state of the psychopathic must be understood in order to avoid their violent behavior because they suffer from psychopathy due to social family problems and eventually led them to commit murder.
\end{abstract}

\section{INTRODUCTION}

Psychopathy is defined as a mental (antisocial) disorder in which an individual manifests moral and antisocial behavior, shows a lack of ability to love or establish meaningful personal relationships, expresses extreme egocentricity, and demonstrates a failure to learn from experience and other behaviors associated with the condition. It is believed that the notion of psychopathy is widely contested from a theoretical as well as a scientific point of view. Its importance is evident not only in the domain of psychiatry and psychology but also in other disciplines, it nonetheless remains a mental disorder that has not yet been fully discovered. According to (Moreira et al., 2014) mentioned two types of psychopathy primary psychopathy broadly comprises the affective deficits associated with psychopathy and secondary psychopathy which is characterized by the behavioral issues related to the disorder .According to the literature primary psychopathy is most often associated with low emotional empathy and low anxiety (Hale et al., 2004; Honk \& Schutter, 2006) while Secondary psychopathy is mostly associated with high anxiety and low self-control (Ray et al., 2009). While Antisocial personality disorder according to (Litin 2018) personality disorder, sometimes called sociopathy, is a mental disorder in which a person consistently shows no respect for right and wrong and disregards the rights and feelings of others. Individuals with antisocial personality disorder tend to antagonize, manipulate or treat others cruelly or with heartless indifference. They show no guilt, mind conscience, or remorse for their behavior.
My Last Duchess," is a poem which is often considered the superior dramatic monologue of the Victorian era, is the story of the Duke of Ferrara, who believed that his wife did not fulfill his status and did not show him the proper standard of appreciation. In the final display of power and domestic abuse, he murdered her. The Duke is authoritarian, to say the least (Hayward 2008). He expected fundamental acquiescence, from his Duchess: "...if she let/Herself be lessened..." and when he was disappointed, he ordered her death. "I gave commands;/Then all smiled stopped together." He also expected a rising standard of respect to be granted for the name he awarded upon her, yet he felt she "ranked/ my gift of a nine-hundred-years-old name/With anybody's gift." The serious joining made the Duke feels ignored and as the husband and the one with power within the relationship, his discontent in her was made clear through her death. It has been suggested that another reason for the Duke"s murder of his young wife was that he was "somehow horrified by his wife's liberty of spirit, and veiled this fact with exaggerated severity" (Hayward 2008). This is clear in the poem through his urgent call to be in the dominance of her smiles and joy he is the only one who is allowed to make her happy, although he does not seem to matter about doing so.

\section{LITERATURE REVIEW}

For different reasons, Psychopaths suffer from emotional ache. As with anyone else, they believe that must be loved and cared for. In the poem "My Last Duchess" the duke wanted his wife to love him and care for him. However, this wish remains unfulfilled because it is clearly not easy 
for any person to get close to someone with such repulsive personality characteristics. Psychopaths feel upset by their inability to control behavior. The lives of most psychopaths have lacked stable social life or warm, close relationship between people.

(Martens 2014) explained that regardless of their external arrogance, psychopaths feel inferior to others and know they are condemned by their own behavior. Some psychopaths feel they must carefully suppress their real nature because it will not be passable to others. This leaves psychopaths with a difficult choice to adapt and participate in an empty, unreal life, or do not adapt and live a lonely life isolated from the social community. They see people share love and friendship and they feel dejected knowing they will never be part of it. (Martens, 2000) assured that the life histories of psychopaths are often characterized by chaotic family life, lack of parental attention and guidance, parental addiction abuse and antisocial behavior, poor relationships, divorce, and reverse neighborhoods.

It is known that psychopathy is characterized by diagnostic features such as superficial charm, high intelligence, poor judgment and failure to learn from experience, pathological egocentricity and incapacity for love, lack of remorse or shame, impulsivity, grandiose sense of self-worth, manipulative behavior, poor self-control, pathological lying, promiscuous sexual behavior, juvenile delinquency, and criminal versatility among others (Cleckley, 1982; Hare et al., 1990). As a consequence of these criteria, the psychopath has the image of a cold, heartless, human being. But do all psychopaths show a complete lack of normal emotional capacities and empathy? Like healthy people, many psychopaths love their parents, spouse, children, and everything in their own way, but have difficulty in loving and trusting the rest of the world. Furthermore, psychopaths suffer emotionally as a consequence of separation, divorce, death of a beloved person, or dissatisfaction with their own deviant behavior (Martens, 1997). )Cleckley 1988) believes that the man who is essentially criminal may be regarded as consistently purposive, whereas the psychopath on the other hand seems hardly purposive at all. According to) D.J. Cooke et al 2005) experiments have been conducted for more than half a century, indicating that people who commit crimes and behave violently statistically are more likely to suffer from major mental disorders than to be non-disordered.

\section{RESULT AND DISCUSSION}

\section{Similarities and differences between Sociopathy and Psychopathy}

According to (The American Psychiatric Association in 2013), lists both sociopathy and psychopathy under the heading of Antisocial Personality Disorders (ASPD). These disorders share many common behavioral characteristics, which lead to some confusion. Key traits that sociopaths and psychopaths share include: A disregard for laws and social Mores: A disregard for the rights of others A failure to feel remorse or guilt, and a tendency to display violent or aggressive behavior

The specific traits as identified by (Hare1990) in his psychopathy checklist are the following; Glowing and superficial charm arrogant self-esteem; the need for stimulus, pathological lies, cunning, lack of remorse or guilt; shallow effect of cruelty, and lack of empathy. Parasitic lifestyle Poor behavioral controls Sexual promiscuity, early behavior problems Lack realistic long-term goals; Rush irresponsibility, not taking responsibility for his actions; many short-term marital relationships; juvenile delinquency; abolition of parole and criminal diversity.

According to The American Psychiatric Association in 2013, Sociopaths tend to be nervous and easily agitated. They are unsteady and prone to emotional outbursts, including fits of rage. They are more likely than are psychopaths to be uneducated and live on the fringes of society. They are sometimes unable to hold down a steady job or to stay in one place for very long. It is often difficult, but not entirely impossible, for sociopaths to form attachments with others.

Many sociopaths are able to form an attachment to a particular individual or group, although they have no regard for society or its rules in general. Therefore, the meaningful attachments of any sociopath will be few in number and limited in scope. As a rule, they will struggle with relationships.

Robert Browning in 1842 was an English poet of the Victorian era, who was widely known as a leader of dramatic monologues and psycho-portraits. "My Last Duchess" poem talks about the Duke, who is the speaker in the poem, and the Duke discusses his marriage. He shows his visitor his palace when he stops where there is a picture of the late Duchess. A beautiful portrait of a beautiful lady with a charming smile, he began to explain to his visitor that he did not like the behavior of the late Duchess. Psychopaths can experience emotional pain for a variety of reasons. As with everyone else, psychopaths have a deep desire to be loved and cared for. What the Duke had obviously lost was when the Duke wanted in "My Last Duchess" the Duke wanted his wife to make him feel special but he never tried to talk and discuss with her about it and this is one of the reasons in that era women were dominated by men. It is clear that it is not easy for another person to approach a person with such unpleasant personality traits. Psychopaths at least periodically become aware of the effects of their behavior on others and can feel really sad about their inability to control it. Most psychopaths lack a stable social life or a warm, close relationship between people.

Robert Browning has focused upon the dark aspects of human nature in his poem "My Last Duchess". The poem is about a psychopath disorder dominating individual who practices his rule and power over his late duchess. The poem forces the reader to realize the complicated nature of a man 
that is covered by psychopath symptoms which makes him so savage that he can put an end to the life of his wife who neglects him and doesn't act according to her social position. The speaker of the poem is a self-obsessed person who beliefs that the portrait of his deceased Duchess is his own property and he doesn't appreciate the portrait of his duchess but its painting. According to (Greenblatt et al.2006) the story goes that Alfonso's first wife Lucrezia died under questionable events after only three years of marriage. Following her death, the Duke negotiated through an emissary to marry a niece of the Count of Tyrol. The incidents of the poem evolve around the Duke who is giving the appointed emissary a tour around his palace and showing off his extensive art collection. In the opening scene, the two noblemen have stopped to admire a painting of the late Duchess. Judging from the way the Duke speaks and attends to his visitor, his discourse is highly polished and his manners aristocratic. However, from the Duke's one-sided monologue the reader can reconstruct a story quite different from the one the Duke believes he is telling. As ( Loehndorf 1997, 166) puts it, Browning's monologues show that the speakers' account of their own character is not entirely accurate. While discussing the portrait, the Duke starts to remember with pleasure his late wife and at the same time reveals himself as a despotic and pathologically jealous husband who wanted to keep the Duchess as his possession. This proved one of the characteristics of Victorian men who dominating women in that era.

According to Merriam-Webster dictionary, the word power means possession of control, authority, or influence over others. The construction of Victorian society places men as superior to women. Therefore the Duke feels he has taken control once he kills the Duchess. According to (Ismet Ozkilic1996), a graduate of the University of Central Oklahoma Graduate College points out that the Duke feels a sense of "absolute control" because the reader and the envoy do not know the Duchess's point of view of the story, however, the Duke, like many Victorian men, does not realize that "such selfishness helps reinforce their imminent weakness. Men in the Victorian period have the ability to hush women so that only a man's point of view is heard, therefore leaving no objection. Unfortunately, men such as the Duke become dependent on women's pause. The Duke wanted to dominate and rule his Duchess in every way. Some critics say that the Duke's reason for killing the Duchess is because of his feeling of being socially inferior by the Duchess's actions when she was smiling at all guests who meet her. "Therefore, the Duke interprets the Duchess happiness as impudence and revolt against her social superior, surrogate and master, the Duke."(Fatima H.Aziz and Ameen U. Ghailan 2008.) He wanted her smiles, and happiness to be directed only toward him. The Duchess's warm and intimate personality menace the Duke's power. So much so that the Duke was nauseated by the Duchess's warmth toward anyone rather than himself (Browning line 38). Unfortunately, the Duke was so disturbed in controlling the Duchess that he did not want her to even look at other people. Men were dominating women which was a very important aspect of the Victorian era. The duke had no control over his Duchess when she was alive.

According to (Marchino 1992) when the Duchess was alive, the Duke had no control over what she was exposed to. Now that the Duchess is dead "[the Duke]...he can open or close the curtain as he pleases: he can apply total dominance. This showed another factor why men in the Victorian era could not have a dialogue with their married couple to discuss minor issues this showed total dominance." The Duke expresses to the envoy that "the appearance of the Duchess has gone everywhere" (Browning line 24). This means that although his Duchess passed, he is concerned about her looks and the Duchess treats all people with respect. The thing that was given to the Duke is that this respect is his right and must be given.

Another concept is arrogance according to Merriam Webster Arrogance is an attitude of superiority manifested in an overbearing manner in presumptuous claims or assumptions or adrogare which means that to feel that one has a right to demand certain attitudes and behavior from other people.

\section{"She thanked men, - good! but thanked}

\section{Somehow - I know not how - as if she ranked}

\section{My gift of a nine-hundred-years-old name}

\section{With anybody's gift."}

In these lines, the researcher focuses on the arrogance of the duke and he was also an arrogant and proud individual who was only concerned about his wealth, fame, and his title. When the Duke showed that his duchess expresses gratitude to everybody for whatever favor one did to her just like she appreciates the duke who gave her a position as a duchess. His sound grows harshly as he remembers how both human and nature could impress her, which offended him since she did not give special favor to the "gift" of his "nine-hundred-yearsold" family name and parentage. To him, it was degrading that the duchess contemplates everything in the same way. The status that the duke had given her by marrying could never be compared to other ordinary gifts. He could never feel the esteem and love of the duchess towards him.

The Duke disclosed his jealous nature by rejecting the Duchess's tendency to give just as much of her attention to insignificance, like a beautiful sunset or a ride on a white mule (26-28), as she did to her husband. The Duke believed the Duchess unintentionally wounded his pride and made him jealous by accepting compliments and politeness from common people as the purpose for friendliness

\section{Half-flush that dies along her throat:' such stuff}

Was courtesy, she thought, and cause enough 


\section{For calling up that spot of joy. She had}

\section{A heart-how shall I say?-too soon made glad,}

(Hauck 1981,15) indicates that there is "no concurrence in a jealous person's life " where every detail or event is regarded as sufficient proof of the loved one's disloyalty. In the Duke's case, this is exemplified by the following words:

"Oh sir, she smiled, no doubt, /

\section{Whene'er I passed her; but who passed without /}

\section{Much the same smile?" (43-45)}

Then again, (Thomas Blackburn 1967, 60) suggests that the Duke felt deceived by his wife's gladness in everyday pleasures and her friendliness towards all acquaintances. I agree with Blackburn on this point and argue that the Duke was so jealous of his wife's care that every "accepting speech" (30) she steered to something or someone else was a personal affront for him, as the Duke hoped to be the only origin of his wife's gladness. Unable to succeed in this pretension the Duke quits from all responsibility by claiming that.

\section{For calling up that spot of joy. She had}

\section{A heart-how shall I say? - too soon made glad,}

\section{Too easily impressed; she liked whate'er}

\section{She looked on, and her looks went everywhere.}

\section{" (21-23)}

If the Duchess felt her husband's feelings and tried to stop the smiles and accept thanks from all people, the Duke would not feel the jealousy that led him to commit the crime. Among the features identified by Hare1990 in the Special Psychopathology Checklist are: rushing irresponsibility, lack of responsibility for his actions and many short-term marital relationships; and criminal diversity.

Plausibly the Duke boosted a risky fright of being discarded by his wife. (Hauck 1981, 27) comments on the same phenomenon on a more general level by pointing out that jealous people have a tendency to feel threatened when their loved ones show completely innocent interest in anyone or anything that does not make the jealous partner the center of attention. I can add to Hauk's words that all psychopath patients have the same phenomenon they suffer from shortterm marital relationships; juvenile delinquency; they find ignorance from their spouses. This issue can be solved I blame both the duke and the duchess why they do not create a romantic dialogue between them. The Duke describes the last Duchess as if she were wanton with her attention, inadequately class conscious and overly friendly .

\section{she does anyone else.}

\section{She loves everyone and everything:}

"she had a heart too soon made glad,

too easily impressed".
She enjoys life and people and does not differentiate between nature and art, high or low class, men in general, and her husband with the 900-year-old name.

Again the duke praised his duchess by saying she is not a tough woman

\section{-she blushes easily too easily,}

According to the Duke, and too frequently as well). She smiles at everyone friendly, without differentiation so, and she thanks everyone this makes her too free with her gratitude. As far as the Duke is concerned, she should only be thankful to him for giving her his name and title. According to (Silver et al .1999. ( "Psychopathy's defining characteristics, such as impulsivity, criminal versatility, callousness and lack of empathy and remorse, make the conceptual connection between violence and psychopathy straightforward." In the attempt to understand the relation between psychopathy and criminal behaviour, it must be noted that psychopaths compile only approximately $1 \%$ of the global population but they represent $25 \%$ of the prison population in the United States and 4\% among corporate CEOs. these statistical fact advocates in favour of the argument that psychopathy and criminal behavior are correlated, further research is however needed in order to indubitably prove this .

Based on the evidence from the poem, it is clear that the Duke suffers from insecurities and fear provoked by jealousy, which seems to be one possibility, he fears the disgrace that the last Duchess will cause him. Failing in his attempts to control his wife, the Duke decided to take extreme measures and so on.

\section{gave the command;/}

\section{Then the smiles stopped "(45-46).}

In my opinion (Bataille 1986, 20) provides a reliable explanation for the Duke's behavior by claiming that "if a lover cannot possess the lover, he will sometimes think of killing her ..." Although the meaning of the commands is never specified, there is reason to suppose that the duke arranged the murder of his wife.(Germain 1957, 493) notes that pride blinded the Duke when he made the decision to get rid of his wife. Indeed, it must be said in all fairness that pride appears to have played a major role in the Duke's behavior. It appears in the poem that the Duke was insulted and humiliated by having to reprimand his wife, whose obedience should have been a truism: In my opinion, the Duke reveals his jealous nature by rejecting the Duchess' tendency to devote as much as her attention to trifles, such as a beautiful sunset or riding on a mule White (26-28), as she did with her husband. Moreover, the Duchess unwittingly wounded her husband's pride and made him jealous by accepting flattery and familiar politeness from others as reasons for plain affection, "such t.hings / were a compliment, I thought, and cause enough / to reach the point of joy" (19-21) ). Hauck $(1981,15)$ points out that "there are no accidental coincidences in the world 
of a jealous person" where every detail or event is taken as enough evidence of treachery. It is true, Hawke's words, for the Duke, was jealous of his wife's concern for others without regard to him and the high societal status he was given everything could be changed if the duchess behaves in a different way for example by not accepting appreciation from ordinary people and care a little about her husband who was psychopathic.

Sociopathy is likely the product of childhood trauma and physical or emotional abuse or insult. Sociopathy appears to be learned rather than inborn, sociopaths are able to empathy in some situations, and with particular individuals, but not with others. Eventually, psychopathy is infrequent than sociopathy and is considered to be the most dangerous of antisocial personality disorders.

\section{CONCLUSION}

It is very important to recognize suffering, loneliness, and low self-esteem as risk factors for psychopathic violent criminal behavior. The diagnosis of violent criminal psychopaths sheds light on the staggering and specific vulnerability and relentless emotional pain that was the main cause of the Duke's vital jealousy turned into hatred and murder. Browning's poem, The Last Duchess Lee, focused on the inability of psychopaths to control their jealousy, pride, and arrogance. The Duke introduces us to his dark and ominous nature, which in turn prompted him to commit his crime because he was unable to solve the dilemma. The nobles like the duke lived with unconditional sovereignty dignity, confidence, and unstoppable power.

\section{Recommendation}

The researcher recommends that there is a need for more research in the common psychological treatment to prevent and treat psychopathic behavior, and to know the main reasons that lead to some symptoms such as lack of remorse, arrogance, and destructive jealousy that leads to committing.

\section{REFERENCE}

1. American Psychiatric Association. (2013). Diagnostic and statistical manual of mental disorders (5th ed.). Washington, DC: American Psychiatric Association. Cross Ref Google Scholar

2. Andrew E.Skodol,(1998) Psychopathology and Violent Crime American Psychiatric Press 1998

3. Aziz, Fatima H and Ameen U. Ghailan.(2008) "Dramatic Monologue in Robert Browning"s „My Last Duchess": A Pragma-Stylistic Study." University of Basrah: Studies in English. Eds. Jinan Fedhil Al-Hajaj and Graeme Davis. Germany: International Academic Publisher, 2008. Print.

4. Bataille, Georges. 1986 (1957). Erotism: Death and Sensuality. San Francisco: City Lights Books.
5. Cleckley HM (1982). Mask of Sanity: An Attempt to Clarify Some Issues about the So-Called Psychopathic Personality. 6th ed. St Louis: CV Mosby Co; 1982.

6. D.J. Cooke, C. Michie, S.D. Hart, and D. Clark, (2005) Searching for the pan-cultural core of psychopathic personality disorder, Personality and Individual Differences 39: 283-295.

7. E. Silver, E. Mulvey, and J. Monahan, (1999) Assessing violence risk among discharged psychiatric patients: Toward an ecological approach. Law and Human Behavior, 23, 235-253

8. Greenblatt, Stephen, et al., eds. The Norton Anthology of English Literature. 8th ed. New York: W. W. Norton \& Company, Inc., 2006. Print

9. Hale, L., Goldstein, D., Abramowitz, C., Calamari, J. \& Kasson, D. (2004). Psychopathy is related to negative affectivity but not to anxiety sensitivity. Behaviour research and therapy. 42. 697-710.

10. Hare RD, Harpur TJ, Hakstian AR etal. (1990), The Revised Psychopathy Checklist: descriptive statistics, reliability, and factor structure. Psychological Assessment 2:338341.

11. Hauck, Paul A. 1981. Overcoming jealousy and possessiveness. Louisville: The Westminster Press.

12. Hervey M. Cleckley (1988) The Mask of Sanity (5th edn Emily S. Cleckley (ed)

13. Honk, J. \& Schutter, D. (2006). Unmasking feigned sanity: A neurobiological model of emotion processing in primary psychopathy. Cognitive neuropsychiatry. 11 (3). 285-306

14. Jerman, B. R. 1957. "Browning's Witless Duke.” PMLA 72, 3: 488-493.

15. Marchino, Lois A. 1992 ) Masterplots II Poetry Series. Vol. 4. Pasadena, California and Englewood Cliffs, New Jersey:: Salem P.,

16. Martens WH, Palermo GB.( 2005) Loneliness and associated violent antisocial behavior: analysis of the case reports of Jeffrey Dahmer and Dennis Nilsen. Int J offender Their Comp Criminol. 2005;49:298-307.

17. Martens WH. (2011) Sadism linked to loneliness: psychodynamic dimensions of the sadistic serial killer Jeffrey Dahmer. Psychoanal Rev. 2011;98:493-514.

18. Martens WHJ (1997), Psychopathy and maturation. MD-dissertation, Tilburg University, The Netherlands. Maastricht: Shaker Publishing.

19. Martens WHJ (2000), Antisocial and psychopathic personality disorders: causes, course and remission --a review article. International Journal of Offender Therapy and Comparative Criminology 44:406-430 
20. Martens, Willem H.J.(2021) "The hidden suffering of the psychopath." Psychiatric Times, vol. 31, no. 10, 2014, p. 1. Accessed 3 Mar. 2021.

21. Moreira, D., Almeida, F., Pinto, M. \& Favero, M. (2014). Psychopathy: A comprehensive review of its assessment and intervention. Aggression and violent behaviour. 19. 191-195.

22. Ozkilic, Ismet.(1996) "Male Gender-Insecurity vs. Domination in Two Dramatic Monologues by Robert Browning: 'My Last Duchess' and 'Porphyria's Lover."' Edmond, Oklahoma: University of Central Oklahoma Graduate College P., 1996.
23. Raine and J. Sanmartin,( 2001) Violence and Psychopathy (Kluwer 2001)

24. Ray, J., Poythress, N., Weir, J. \& Rickelm, A. (2009). Relationships between psychopathy and impulsivity in the domain of self-reported personality features. Personality and individual differences. 46. 83-87

25. Scott C. Litin(2018) Mayo Clinic Family Health Book 5th Edition Mayo Clinic Press

26. Theodore Millon and Roger Dale Davis,(1996) Disorders of Personality: DSM-IV and Beyond (2nd ed John Wiley \&Sons 1996).

Citation: Dr. AMAL. M. A. IBRAHIM, “"My Last Duchess” Poem from a Psychosocial and Social Point of View”, American Research Journal of English and Literature, Vol 7, no. 1, 2021, pp. 1-6.

Copyright (C) 2021 Dr. AMAL. M. A. IBRAHIM, This is an open access article distributed under the Creative Commons Attribution License, which permits unrestricted use, distribution, and reproduction in any medium, provided the original work is properly cited. 